\title{
TECHNIQUES AND ANALYSIS OF MANAGEMENT AUDITS
}

\section{Peter Gallo, ${ }^{1}$ Romana Píchová, ${ }^{2}$ Anna Šenková, ${ }^{3}$ Daniela Matušíková, ${ }^{4}$ Jana Mitríková ${ }^{5}$}

\begin{abstract}
The proper management of an enterprise involves a set of complex activities that, in the current rapidly changing world, require adoption of modern market requirements. This paper describes a study concerning management audits. The study aims to identify and evaluate the specific techniques that are useful for obtaining information for audits in evaluating management, and examines modifications and applications of the model by McKinsey, 'model 7S', with an 'IFE Matrix'. As practice shows, until now, the 'model 7S' approach is the most frequently used tool to assess the current state of management executives in business. The proposed models in the paper's conclusion can be used individually or by combining two separate models to create a 'two-staged adaptive model 7S'.
\end{abstract}

JEL Classification Numbers: M42; DOI: http://dx.doi.org/10.12955/cbup.v5.914

Keyword: management audit, model 7S, Adaptation model 7S, effectiveness, efficiency

\section{Introduction}

The main goal of most enterprises is continued improvement of their management system, which requires, in particular, an understanding of the current state regarding its strengths, and weaknesses, and a proposal to improve or overhaul the system where needed. The management of the company must first approve the audit of the management system in their company as a prime activity.

Many authors have defined the requirements of a management audit. For example, Law (2009) defines a management audit as an independent review of corporate governance, which is executed by professional management consultants, specializing solely in this type of review.

According to the authors, Wheelen and Hunger (2012), a management audit can be described as an analysis of business management with the audit compiling a list of questions from various areas of management and areas that affect management with the aim of receiving objective and honest responses.

The simplest definition of a management audit is given by David (2011), who characterized management audit as a gathering and evaluation of information about management activities within the company.

As the above characteristics indicate, a management audit is a special type of business management support, not a supervisory authority that only searches for errors and weaknesses. A management audit serves managers or management leaders as an administration tool since it has to provide impartial information about management systems used in the enterprise (Spencer, 2011).

All activities implemented in the management audit are performed by specialized personnel, who must not only know the theory and principles of corporate planning, organization, and management, but also business practices (Kotler, 2013).

According to Trunečka (2004), a management audit aims to identify and assess the current state of corporate governance, i.e., to identify and characterize problems in the company that prevent effective management.

Other management techniques, such as controlling, benchmarking, and internal analysis methods, are also used to assess the current stage of management. Examples given by Gallo (2013) include a Balanced Scorecard; a Space Analysis; the Strengths, Weaknesses, Opportunities, and Threats $(\text { SWOT) })^{6}$ analysis; Internal Factor Evaluation (IFE) matrix of business processes; and an analysis of the key factors based on the model 7S proposed by McKinsey (Schawel, Billig, 2012). This paper

\footnotetext{
${ }^{1}$ Faculty of management, Prešov University, Slovakia, peter.gallo@unipo.sk

${ }^{2}$ Faculty of Management, Prešov University, romca.pichova@gmail.com

${ }^{3}$ Faculty of Management, Prešov University, anna.senkova@unipo.sk

${ }^{4}$ Faculty of Management, Prešov University, daniela.matusikova@unipo.sk

${ }^{5}$ Faculty of Management, Prešov University, jana.mitrikova@unipo.sk
} 
describes a modified version of the '7S Model' proposed by McKinsey (McDonald, D. 2014) and its application as a tool to assess the current state of management within the business.

\begin{tabular}{|c|c|c|c|c|c|}
\hline \multirow{3}{*}{ Factors } & \multirow{3}{*}{ Evaluation indicators } & \multicolumn{2}{|c|}{ Evaluation parameters } & \multicolumn{2}{|c|}{$\begin{array}{c}\text { Overall } \\
\text { rating }\end{array}$} \\
\hline & & $\begin{array}{l}\text { 1. Efficiency } \\
(\max .5)^{7}\end{array}$ & $\begin{array}{l}\text { 2. Effectiveness } \\
(\max .5)^{8} \\
\end{array}$ & 1. & 2. \\
\hline & & $0-5$ & $0-5$ & $0-5$ & $0-5$ \\
\hline Structure & $\begin{array}{l}\text { Flexibility; } \\
\text { Centralization - } \\
\text { Decentralization of } \\
\text { cognizance; Levels and } \\
\text { range of management; } \\
\text { Corporate bonds and } \\
\text { relationships }\end{array}$ & $\begin{array}{l}\text { entry points of the } \\
\text { evaluation questions - area } \\
\text { structure }\end{array}$ & $\begin{array}{l}\text { entry points of the } \\
\text { evaluation questions - } \\
\text { area structure }\end{array}$ & $\sum$ & $\sum$ \\
\hline Systems & $\begin{array}{l}\text { Communication } \\
\text { system; System of } \\
\text { utilization of enterprise } \\
\text { resources; system of } \\
\text { used management } \\
\text { methods and } \\
\text { techniques; adaptation } \\
\text { to the enterprise }\end{array}$ & $\begin{array}{l}\text { entry points of the } \\
\text { evaluation questions - area } \\
\text { systems }\end{array}$ & $\begin{array}{l}\text { entry points of the } \\
\text { evaluation questions - } \\
\text { area systems }\end{array}$ & $\sum$ & $\sum$ \\
\hline $\begin{array}{l}\text { Manage- } \\
\text { ment style }\end{array}$ & $\begin{array}{l}\text { Appropriateness; } \\
\text { Flexibility; Limitation } \\
\text { of Liability of } \\
\text { managers; Use of } \\
\text { Managers' power }\end{array}$ & $\begin{array}{l}\text { entry points of the } \\
\text { evaluation questions - area } \\
\text { management style }\end{array}$ & $\begin{array}{l}\text { entry points of the } \\
\text { evaluation questions - } \\
\text { area management } \\
\text { style }\end{array}$ & $\sum$ & $\sum$ \\
\hline Group & $\begin{array}{l}\text { Qualifications and } \\
\text { education (training) of } \\
\text { employees; } \\
\text { Work environment and } \\
\text { relationships in the } \\
\text { workplace; Motivation } \\
\text { and stimulation of } \\
\text { employees; Evaluating } \\
\text { and rewarding of } \\
\text { employees }\end{array}$ & $\begin{array}{l}\text { entry points of the } \\
\text { evaluation questions - area } \\
\text { groups }\end{array}$ & $\begin{array}{l}\text { entry points of the } \\
\text { evaluation questions - } \\
\text { area groups }\end{array}$ & $\sum$ & $\sum$ \\
\hline Skills & $\begin{array}{l}\text { Ability to plan; Ability } \\
\text { to organize; Ability to } \\
\text { manage; Ability to } \\
\text { control }\end{array}$ & $\begin{array}{l}\text { entry points of the } \\
\text { evaluation questions - area } \\
\text { skills }\end{array}$ & $\begin{array}{l}\text { entry points of the } \\
\text { evaluation questions - } \\
\text { area skills }\end{array}$ & $\sum$ & $\sum$ \\
\hline Strategy & $\begin{array}{l}\text { Appropriateness; } \\
\text { Intelligibility and } \\
\text { clarity; Acceptability } \\
\text { and feasibility; } \\
\text { Backlogs in shorter- } \\
\text { term methods }\end{array}$ & $\begin{array}{l}\text { entry points of the } \\
\text { evaluation questions - area } \\
\text { strategy }\end{array}$ & $\begin{array}{l}\text { entry points of the } \\
\text { evaluation questions - } \\
\text { area strategy }\end{array}$ & $\sum$ & $\sum$ \\
\hline $\begin{array}{l}\text { Shared } \\
\text { values }\end{array}$ & $\begin{array}{l}\text { Aims; Vision; Mission; } \\
\text { Role }\end{array}$ & $\begin{array}{l}\text { entry points of the } \\
\text { evaluation questions - area } \\
\text { of shared values }\end{array}$ & $\begin{array}{l}\text { entry points of the } \\
\text { evaluation questions - } \\
\text { area of shared values }\end{array}$ & $\sum$ & $\sum$ \\
\hline
\end{tabular}

\footnotetext{
${ }^{7}$ Efficiency signifies a level of performance that describes a process that uses the lowest amount of inputs to create the greatest amount of outputs.

${ }^{8}$ The degree to which something is successful in producing a desired result; success.
} 
An important characteristic of a management audit is that, it does not have fixed or mandatory procedures or standards. While these are controls that an auditor could use, a management audit has a creative form (Kumar \& Sharma, 2015).

The function of a management audit in the company itself does not need to be established but can be secured from external sources by outsourcing the management audit. Managers or the company management leaders must assess and choose the form of management audit needed (Montana \& Charny, 2008).

\begin{tabular}{|c|c|}
\hline Factors & Evaluation questions \\
\hline Structure & $\begin{array}{l}\text { Is organizational structure of the enterprise flexible? Is the number of degrees of } \\
\text { management corresponding to the specifics of the enterprise? Are there in the enterprise } \\
\text { defined relations of subordination and superiority? Is it set the degree of centralization or } \\
\text { decentralization of powers to subordinates enough? Is the number of subordinate } \\
\text { employees to individual managers optimum? Is it conveniently used a range of enterprise } \\
\text { management? }\end{array}$ \\
\hline Systems & $\begin{array}{l}\text { Are there used appropriate methods and techniques of communication in the business? Is it } \\
\text { used in the optimal enterprise combination of business resources? Are there used } \\
\text { appropriate and modern management methods and techniques in the business? Can } \\
\text { enterprise correctly respond to changes in its corporate neighborhood? Are there used } \\
\text { appropriate information systems in the enterprise? }\end{array}$ \\
\hline $\begin{array}{l}\text { Management } \\
\text { style }\end{array}$ & $\begin{array}{l}\text { Do the managers use the appropriate leadership style to subordinates in the enterprise? Do } \\
\text { the managers adapt their management style in the company according to the current } \\
\text { situation in the company? Is there clearly defined the responsibility of managers and their } \\
\text { subordinates in the company? Do the managers use the possibility of delegating powers to } \\
\text { subordinates, so they do not abuse their power of supervisor? Is teamwork the used? }\end{array}$ \\
\hline Group & $\begin{array}{l}\text { Does the enterprise have optimal - sufficient number of staff? Is qualification of employees } \\
\text { optimal to perform their job responsibilities? Do the workers have the opportunity for } \\
\text { career growth and progress? Are the job descriptions of individual employees defined } \\
\text { (including the definition of their responsibilities)? Do the managers use appropriate style } \\
\text { and way of motivation and evaluation of subordinates? }\end{array}$ \\
\hline Skills & $\begin{array}{l}\text { Can managers (at all hierarchical levels) independently plan, organize, manage and control? } \\
\text { Can managers (at all hierarchical levels) build plans so that they complement each other } \\
\text { and follow up on? Can managers and their subordinate staff employ a self-management } \\
\text { method? Do the managers (at all hierarchical levels) use the control of the management and } \\
\text { control feedback? Is the ability of managers and their subordinate staff enough for their job } \\
\text { performance? }\end{array}$ \\
\hline Strategy & $\begin{array}{l}\text { Does the enterprise have properly and clearly articulated corporate strategy? Is the } \\
\text { corporate strategy sufficiently and appropriately developed in shorter-term policies and } \\
\text { activities? Does the enterprise have a business concept, how to reach the set strategy most } \\
\text { easily and implement it? Does the enterprise have appropriately formulated and set its } \\
\text { business objectives and elaborated the concept of how to achieve business goals? Are there } \\
\text { developed business objectives, vision, and strategy realistic and feasible? }\end{array}$ \\
\hline $\begin{array}{l}\text { Shared } \\
\text { values }\end{array}$ & $\begin{array}{l}\text { Are the managers and their subordinate workers familiar enough with the policy, } \\
\text { objectives, vision, mission, mission, and strategy of the company? Are managers and their } \\
\text { subordinate staff adequately and timely informed about events in the company? Do the } \\
\text { managers and their subordinate staff act in accordance with the established values and } \\
\text { objectives of the company? Are there clear delimitated competencies of all workers in the } \\
\text { company and the workers know each other? Has the enterprise formed its corporate culture } \\
\text { with which all employees are aware of? }\end{array}$ \\
\hline
\end{tabular}

Source: Authors 


\section{Data and Methodology}

The 7S Model was modified based on responses from structured interviews with experts in the field of auditing with a specific focus on issues of management audits and of managers who personally processed management auditing in their companies. The research was conducted in the Czech Republic, 2015 - 2016, and was centered on small- and medium-sized enterprises (employing 11-250 employees). From the possible internal analyses of management audits, the 7S Model, IFE matrix, and SWOT analysis were the most convenient and most preferred methods of the respondents and hence considered the best methods to assess the current state of corporate governance.

The 7S Model was selected as a basis for a new evaluation model (Adaptation of 7S Model) of the present state of management from the above methods. The reason for choosing this approach was that it not only is used as the main tool for internal analysis of the company, but it simultaneously analyzes the influence of elements of greatest importance in business management.

The overall assessment of the current state of business management was based on point. The scale in the evaluation parameters of the individual evaluation factors was chosen according to the choice of Likert five-point scale.

\section{Results and Discussion}

The application of an 'Adaptation of 7S Model' involved separate factors (Table 1), emphasizing consistency and harmony. Among such factors in the 'Adaptation of $7 \mathrm{~S}$ Model' were structure, systems, style, group skills, strategy, and shared values, that were contained in the original model. Furthermore, certain factors involved evaluation indicators as well as a set evaluation parameter.

Evaluation indicators were assigned based on the results of respondent surveys. The requirement of respondents was to assignee a maximum of four evaluation indicators for each factor. The evaluation questions were prepared, based on the results of interviews with managers within the companies.

The evaluation parameters were chosen for efficiency and effectiveness, based on the work of the renowned management consultant, Drucker (1974), who considered any management activity to be viewed from these perspectives with effectiveness meaning performing requirements successful and efficiently means performing requirements successfully, in a way to avoid waste.

Evaluation questions were drawn for each factor to correspond to the evaluation indicator of each. The number of selected and assigned questions for every factor was five, and hence, five was the maximum score for each. The compiled questions are shown in Table 2.

The principle of the current state of governance evaluation based on the above model in Table 1 consisted of assessing replies to the set questions in Table 2 in terms of efficiency and effectiveness. Questions were constructed so that the answer was either yes or no. This evaluation system is shown in Figure 1. ${ }^{9}$

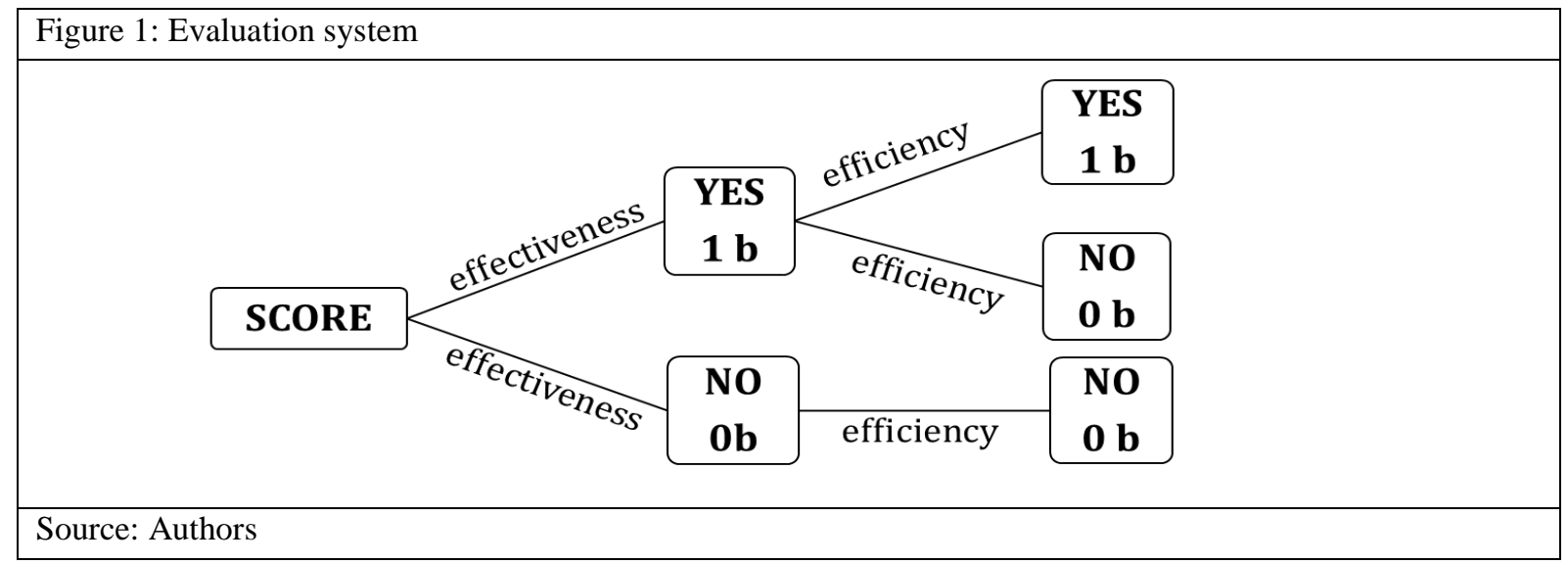

The principle of assessing the current state of management, corresponding to Figure 1, is as follows:

\footnotetext{
${ }^{9}$ The system for evaluating the answers to the questions in Table 2 in terms of efficiency and effectiveness. The answer could be yes or no.
} 
1. Setting of evaluation questions for each factor listed in Table 2

2. Obtaining answers to these set questions, first in terms of effectiveness, where

a. Zero is assigned to a negative answer regarding the effectiveness and also means a negative response to the question relating to efficiency, which thus scores a zero (when the activity in the enterprise is not provided, it is not able to be evaluated).

b. One is assigned to a positive answer regarding effectiveness and means that the company carries out the activity and can further proceed to evaluate the response to the question in terms of efficiency.

3. Answers to these set questions for efficiency, where

a. Zero is assigned to a negative answer regarding efficiency, where the company carries out the activity effectively, but inefficiently.

b. One is assigned to a positive answer to the question from the perspective of efficiency and means that the company carries out the activity effectively and efficiently.

4. The total assessment is a simple sum of points with a maximum of 10 points for each evaluated factor. The ranges of evaluation points achieved are shown in Table 3.

For ease of quantitation, the evaluation questions were the same for effectiveness and efficiency.

\begin{tabular}{|c|l|c|c|}
\hline Table 3: Scoring ranges of assessment factors \\
\hline $\begin{array}{c}\text { Evaluations of } \\
\text { Adaptation of } \\
\text { 7 S Model }\end{array}$ & Level of Effectiveness and Efficiency & $\begin{array}{c}\text { Total point (p) } \\
\text { evaluation of each } \\
\text { factor }\end{array}$ & $\begin{array}{c}\text { Total point } \\
\text { evaluation of } \\
\text { Adaptation of } \\
\text { 7 S Model }\end{array}$ \\
\hline A & High & $\sum 10-9 \mathrm{p}$ & $(10-9 \mathrm{p})^{* 7}$ \\
\hline B & Appropriate & $\sum 8-7 \mathrm{p}$ & $(8-7 \mathrm{p})^{* 7}$ \\
\hline C & Average (partial) & $\sum 6-5 \mathrm{p}$ & $(6-5 \mathrm{p})^{* 7}$ \\
\hline D & Low & $\sum 4-1 \mathrm{p}$ & $(4-1 \mathrm{p})^{* 7}$ \\
\hline E & Zero & $\sum 0 \mathrm{p}$ & 0 \\
\hline Source: Authors & \multicolumn{3}{|}{} \\
\hline
\end{tabular}

Table 3 shows evaluations scale. The final rating for evaluation ' $A$ ' represents the best possible score obtained, and the overall final rating for ' $\mathrm{E}$ ' the worst. The ' $\mathrm{A}$ ' evaluation with a score ranging from 70 to 63 is when the company is managed fittingly, and the chosen management system is sophisticated and at a high of proficiency. The 'E' evaluation with zero score points to inadequacy and a poorly chosen management system.

\section{Conclusion}

Every company seeking to be robust and stable, not only in financial aspects but also in corporate organization and management must constantly analyze its management system. For evaluating the current state of business management, it is possible to use many of the already known and used management methods, such as internal benchmarking, internal control, balanced scorecard, and space, SWOT, and process analyses. This paper describes an entirely new and more detailed model, the 'Adaptation of 7S model' for managers of businesses. This model serves to assess the current state of corporate governance and can be used without further modification or with adaptation according to specific needs and requests of the company.

\section{References}

David, F. R. (2011). Strategic Management: Concepts and Cases. New Jersey. Prentice Hall. (93-103)

Drucker P. F. (1974). Management: tasks, responsibilities, practices. New York: Harper and Row. (14-37)

Gallo, P. (2013). Strategický manažment a controllingové analýzy. Prešov: Dominanta. (64-152)

Kotler, P. T. (2013). Marketing Management. 14th ed. Boston: Pearson (691-695)

Kumar, R., Sharma, V. (2015). Auditing: Principles and Practice. 3rd ed. Delhi: PHI Learning Pvt. Ltd. (21-45)

Law, J. (2009). A Dictionary of Business and Management Fifth edition. Oxford: Oxford University Press, DOI: 10.1093/acref/9780199234899.001.0001 (376-377) 
McDonald, D. 2014. The Firm: The Story of McKinsey and Its Secret Influence on American Business. Simon and Schuster. ISBN 978-1-4391-9098-2

Montana, P. J. \& Charnov, B. H. (2008). Management 4th ed. New York Barron's Educational Series (491-503)

Schawel, Ch., Billing, F. 2012. 7-S-Modell. Gabler Verlag, Springer Fachmedien Wiesbaden.

Spencer, P. K. H. (2011). The Internal Auditing Handbook. 3rd ed. Hoboken: John Wiley (21-49)

Truneček, J. (2004). Interní manažerský audit. Praha: Professional Publishing (20-79)

Wheelen, T. L. \& Hunger, D. J. Strategic management and business policy: concepts and cases. 13th ed., Pearson int. ed. Upper Saddle River: Pearson/Prentice Hall (28-41) 